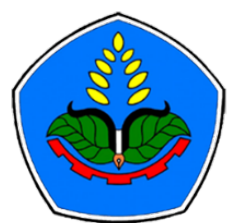

AGROPROSS

National Conference

Proceedings of Agriculture

\title{
Proceedings:
}

Peningkatan Produktivitas Pertanian Era Society 5.0 Pasca Pandemi

Tempat : Politeknik Negeri Jember

Tanggal : 22 Juli 2021

Publisher :

Agropross, National Conference Proceedings of Agriculture

ISBN : 978-623-94036-6-9

DOI : 10.25047 /agropross.2021.205

\section{Analisis Aplikasi Media Tanam Terhadap Pertumbuhan Bibit Tembakau Bes-NO H382 Pada Sistem Pembibitan Semi Float Bed}

\author{
Author(s): Siti Humaida ${ }^{(1)^{*}}$, Diana Nuvita ${ }^{(1)}$, Dinda Ayu Kusumawati(1) \\ (1) Program Studi Produksi Tanaman Perkebunan, Jurusan Produksi Pertanian, Politeknik Negeri Jember \\ *Corresponding author: siti.humaida@polije.ac.id
}

\begin{abstract}
The productivity of Bes-NO H 382 tobacco is strongly influenced by the quality of the seeds. Seed quality will be guaranteed if the application of planting media is in accordance with the nutritional needs for seedling growth while supporting adaptability after moving to the field. The nursery system with semi float bed nurseries is an effort to develop a modern nursery system that uses pot tray. This study aims to analyze the application of planting media in a semi float bed nursery system to the growth of Bes-NO H 382 tobacco seedlings. The study at the Politeknik Negeri Jember in March-May 2020. Using the Randomized Block Design Method with treatment in the form of a comparison of the growing media sphagnum moss and top soil, while the further test used $5 \%$ BNT. The results showed that 1) The growth of Bes-NO H 382 tobacco seedlings in the semi float bed system was influenced by the application of the composition of the growing media with the best seed growth results in the treatment of sphagnum moss: top soil composition of 90:10 and 100:0 with an average seed height of $30.61-4.06 \mathrm{~cm}$, stem diameter $2.48-2.54 \mathrm{~mm}$, wet stover weight 1.84-1.92 grams and dry stover weight 0.15-0.17 grams at 39 days, 2) The number of leaves was not affected by the application of planting media but the adaptability of the seedlings was very good in the field because the percentage of survival of the seedlings reached $75-100 \%$ in all treatments.
\end{abstract}

Keywords:

H 382;

semi float bed;

sphagnum

moss;

top soil.

\begin{abstract}
Kata Kunci: ABSTRAK
H 382;

Produktivitas tembakau Bes-NO H 382 sebagai bahan baku pembalut dan pembungkus cerutu sangat dipengaruhi oleh kualitas bibit. Mutu bibit akan terjamin apabila aplikasi media tanam

semi float bed;

sphagnum

moss; sesuai dengan kebutuhan nutrisi untuk pertumbuhan bibit sekaligus mendukung daya adaptasi setelah pindah ke lapangan. Sistem pembibitan dengan pembibitan semi float bed merupakan upaya pengembangan sistem pembibitan modern yang menggunakan pottray sangat menghemat tenaga kerja dengan pertumbuhan bibit yang sehat dan seragam. Oleh karena itu, penelitian ini bertujuan untuk menganalisis aplikasi media tanam pada sistem

top soil. pembibitan semi float bed terhadap pertumbuhan bibit tembakau Bes-NO H 382. Penelitian dilaksanakan di lahan pembibitan tembakau Politeknik Negeri Jember pada bulan Maret-Mei 2020. Metode Rancangan Acak Kelompok (RAK) faktor tunggal dengan perlakuan berupa perbandingan komposisi media tanam sphagnum moss dan top soil, sedangkan uji lanjut menggunakan BNT 5\%. Hasil penelitian menunjukkan bahwa 1) Pertumbuhan bibit tembakau Bes-NO H 382 pada sistem semi float bed dipengaruhi oleh aplikasi komposisi media tanam dengan hasil pertumbuhan bibit terbaik pada perlakuan komposisi sphagnum moss:top soil 90:10 dan 100:0 dengan rerata tinggi bibit 3,61-4,06 cm, diameter batang 2,482,54 mm, berat brangkasan basah 1,84-1,92 gram dan berat brangkasan kering 0,15-0,17 gram pada umur bibit 39 hss, 2) Jumlah daun tidak dipengaruhi oleh aplikasi media tanam tetapi daya adaptasi bibit sangat baik di lahan karena prosentase hidup bibit mencapai $75-100 \%$ pada semua perlakuan.
\end{abstract}




\section{PENDAHULUAN}

Tembakau (Nicotiana tabacum L.) merupakan komoditas tanaman perkebunan yang berperan penting dalam perekonomian Indonesia, terutama sebagai penghasil devisa negara dan penyerapan tenaga kerja. Penerimaan cukai hasil tembakau (CHT) dari tahun ke tahun menjadi penyumbang terbesar penerimaan cukai total (Nasional). Pada tahun 2020 penerimaan cukai hasil tembakau (CHT) mencapai Rp. 170,2 Trilliun atau 103,2\% dari target Perpres 72 Tahun 2020 dan tumbuh $3,3 \%$ dibandingkan penerimaan tahun 2019. Sedangkan penerimaan cukai total (Nasional) mencapai Rp. 176,31 trilliun (Dirjen Bea dan Cukai, 2021). Industri Hasil Tembakau (IHT) berperan penting dalam menggerakkan ekonomi nasional terutama pada wilayah penghasil tembakau, cengkeh dan sentra-sentra produksi rokok, antara lain menumbuhkan industry jasa terkait , menyediakan lapangan agribisnis dan menyerap tenaga kerja sehingga menimbulkan multiplier effect yang sangat luas (Humaida \& Erawati, 2020).

Tembakau digunakan sebagai bahan cerutu dan rokok Berdasarkan musim tanam tembakau dibagi menjadi dua yaitu tembakau Voor-Oogst (VO) yang di tanam pada akhir musim hujan dan dipanen saat kemarau, dan tembakau NaOogst (NO) di tanam pada akhir musim kemarau dan dipanen pada musim hujan (Siregar, Ginting, \& Meiriani, 2018) (Siregar et al., 2018). Ada beberapa varietas tembakau Besuki Na-Oogst (BESNO) salah satunya varietas H 382 . Tembakau varietas H 382 ini menghasilkan daun yang elastis, tipis, aroma yang baik, selain itu tanaman ini memiliki kelebihan yaitu tahan terhadap serangan hama dan penyakit, tanaman tidak lebih tinggi dari tembakau Na-Oogst varietas lainnyasehingga memudahkan pemanenan.
Pemanfaatan tembakau sebagai bahan pembalut dalam pembuatan cerutu yang bersifat ekspor, menuntut mutu yang tinggi. Penentuan mutu dan produktivitas tembakau dipengaruhi oleh mutu bibit yang merupaka pertumbuhan awal. Mutu bibit berpengaruh terhadap tingkat keberhasilan budidaya tembakau. Pertumbuhan bibit yang baik didukung oleh media tanam yang sesuai, yaitu subur, gembur, porositas baik, tidak mengandung inokulum penyakit, sehingga perlu diperoleh bibit yang sehat dan seragam dengan perakaran yang dapat mendukung daya adaptasi setelah pindah tanam ke lapang.

Salah satu upaya untuk meningkatkan mutu bibit dengan menyiapkan media tanam yang sesuai untuk pembibitan tembakau. Pertumbuhan yang optimal memerlukan media tanam yang memiliki kesuburan yang baik. Media tanam merupakan tempat tumbuh dan berkembangnya perakaran sehingga pemilihan media harus tepat dengan penggunaan bahan organik. Akar tanaman berfungsi sebagai : penegak berdirinya tanaman pada tanah, mengabsorbsi hara dan air, melakukan aktifitas metabolisme tanaman, dan tempat menyimpan cadangan makanan (Kramer, 1977 dalam Islami \& Utomo (1995)

Menurut Wiryanta (2007) dengan menggunakan media sphagnum moss yang berasal dari sejenis lumut, yang mempunyai tekstur lembut, dapat mengikat air sampai $80 \%$ dan mengandung nitrogen $2-3 \%$, sehingga sesuai dengan kebutuhan bibit tembakau yang memerlukan unsur hara dan air yang cukup untuk pertumbuhan bibit yang optimal. Hasil penelitian Saputro (2019), menunjukkan bahwa media tanam sphaghnum moss menghasilkan pertumbuhan bibit tembakau yang terbaik dibandingkan dengan perlakuan komposisi media tanam yang lain (top soil dan kompos). Media sphaghnum moss merupakan media yang 
diimport daril uar negeri, oleh karena itu butuh pembiayaan yang agak tinggi. Upaya untuk menekan biaya digunakan kombinasi media top soil yang mudah dijangkau oleh petani. Top soil banyak mengandung bahan-bahan alami.

Menurut Islami \& Utomo, (1995) lapisan tanah bagian atas (top soil) pada umumnya mengandung bahan organic yang lebih tinggi dibandingkan lapisan tanah dibawahnya. Karena akumulasi bahan organic inilah maka lapisan tanah tersebut berwarna gelap dan merupakan lapisan tanah yang subur, sehingga merupakan bagian tanah yang sangat penting dalam mendukung pertumbuhan tanaman. Tanah top soil mempunyai kedalaman sekitar $20 \mathrm{~cm}$. Selaras dengan pernyataan (Hardjowigeno, 2007) ,tanah lapisan atas (top soil) merupakan tanah yang mengandung humus atau bahan organik, sehingga memiliki C-organik yang lebih tinggi. Bahan organik dapat berasal dari sisa-sisa tanaman yang kemudian mengalami dekomposisi di dalam top soil. Semakin dalam lapisan tanah (subsoil) maka kandungan bahan organik semakin berkurang sehingga tanah semakin kurus.

Sistem pembibitan Semi Float Bed
(SFB) merupakan inovasi sistem pembibitan yang dikembangkan untuk mengantisipasi penggunaan lahan pembibitan yang tidak memiliki drainasi yang baik dan sumber air sedikit, namun masih jarang digunakan oleh petani dan masih perlu banyak penelitian guna mengetahui media yang cocok digunakan dalam sistem ini. Media yang baik adalah media yang memiliki tekstur yang gembur, memiliki unsur hara yang cukup bagi tanaman, dan dapat mengikat air. Sistem pembibitan tembakau semi float bed merupakan sistem pembibitan terapung dengan meletakkan tray di atas bedengan kolam sehingga dapat menghemat penggunaan tenaga kerja. Pemilihan sistem pembibitan ini sangat praktis karena tidak perlu melakukan penyiraman setiap hari, tidak perlu melakukan penyiangan, pertumbuhan bibit seragam, sistem perakaran yang baik, sehingga mampu menghemat tenaga kerja.

Berdasarkan uraian tersebut diatas, maka perlu dilakukan penelitian ini yang bertujuan untuk menganalisis aplikasi media tanam pada sistem pembibitan semi fload bed terhadap pertumbuhan bibit tembakau Bes-NO H 382.

\section{BAHAN DAN METODE}

Penelitian ini dilaksanakan pada bulan Maret hingga bulan Mei tahun 2020. Bertempat di Lahan Percobaan Politeknik Negeri Jember dengan ketinggian \pm 89 mdpl.

Alat terdiri dari cangkul, parang, tang, meteran, gergaji, jangka sorong, nampan, ayakan, alat sterilisasi, timba, water pass, timbangan analitik, knapsack, kamera dan gunting.

Bahan terdiri dari media top soil, sphagnum moss, media sebar pasir halus, kertas merang, pottray, benih tembakau besuki Na-Oogst varietas $\mathrm{H}$ 382, bedengan SFB, bambu, mulsa hitam, plastik transparan, atap WPW, kawat BWG 8, tali rafia, insektisida, fungisida dan nematisida.

\section{Metodologi Penelitian}

Penelitian ini menggunakan rancangan percobaan yaitu Rancangan Acak Kelompok (RAK) Non Faktorial, terdapat 6 perlakuan dan diulang 4x. Adapun faktor perlakuan perbandingan media tanam dalam penelitian ini sebagai berikut:

P0 $=100 \%: 0$ (Sphagnum Moss : Top Soil) P1 $=90 \%: 10 \% \quad$ (Sphagnum Moss : Top Soil)

P2 $=80 \%: 20 \%$ (Sphagnum Moss : Top Soil)

P3 $=70 \%: 30 \% \quad$ (Sphagnum Moss : Top Soil)

P4 $=60 \%: 40 \% \quad$ (Sphagnum Moss : Top Soil) 
P5 $=50 \%: 50 \% \quad$ (Sphagnum Moss : Top Soil)

Cara kerja yang digunakan dalam penelitian ini :

\section{Persiapan Bedengan Pembibitan}

Membersihkan Gulma dan sisa-sisa tanaman. Membentuk bedengan sistem semi float bed, arah bedengan membujur utara-selatan, dengan panjang $4 \mathrm{~m}$ dan lebar $1,5 \mathrm{~m}$. Tinggi bedengan $30 \mathrm{~cm}$ dibuat rata, tinggi kolam $10 \mathrm{~cm}$. Setelah itu membuat atap bedengan waring plasti waring (WPW) yang dibentuk setengah lingkaran dan dikaitkan pada kerangka atap bedengan.

\section{Pembuatan Media Pembibitan.}

Melakukan sterilisasi media top soil pada suhu $100{ }^{\circ} \mathrm{C}$ dan diamkan selama 30 menit, kemudian dikering anginkan. Media sphagnum moss tidak perlu di sterilisasi. Kemudian membuat komposisi media tanam sesuai perlakuan dengan menggunakan sphagnum moss dan top soil. Mengisikan media kedalam pottray yang berisi 162 lubang dengan volume 28 cc, setelah diisi kemudian menata pottray ke bedengan SFB sesuai layout perlakuan.

\section{Pengecambahan Benih}

Benih diperam pada kertas merang yang dibasahi selama 3-4 hari dan diletakkan pada tempat yang lembab. Kemudian benih yang sudah pecah kulit di sebar pada media dalam nampan, hingga umur $14 \mathrm{HSS}$. Setelah itu transplanting bibit dari sebar ke pottray pada umur 14 HSS.

\section{Pemeliharaan Bibit}

Mempertahankan air tetap setinggi $1,5 \mathrm{~cm}-2 \mathrm{~cm}$. Pengendalian hama dan penyakit dilakukan saat terjadi serangan semut dengan insektisida dan secara manual dengan mencari ulat dan telur. Pelaksanaan penyulaman dilakukan umur 14 hss-18 hss.Seleksi bibit meliputi bibit yang sehat, tidak etiolasi, memiliki daun sekitar 5-6, bebas dari hama dan penyakit. Dilakukan buka - tutup atap pada umur 2540 HSS

\section{Penanaman Bibit}

Penanaman bibit untuk mengetahui daya adaptasi di lahan. Sebelum tanam dilakukan pemupukan 1 hari sebelum tanam dengan pupuk KNO3 5 gr/tan urea 5 $\mathrm{gr} / \tan$ dan SP36 $4 \mathrm{gr} / \mathrm{tan}$.

\section{Parameter Pengamatan}

a. Tinggi bibit $(\mathrm{cm})$

Diukur pada umur 25, 32, dan 39 HSS, dari permukaan tanah sampai titik tumbuh.

b. Jumlah daun bibit (helai)

Dihitung pada umur 25, 32, dan 39 HSS, mulai daun bawah sampai daun membuka.

c. Diameter batang bibit (mm)

Diukur pada umur 39 HSS, mulai ketinggian $1 \mathrm{~cm}$ dari permukaan tanah dengan jangka sorong

d. Berat brangkasan basah (gram)

Dilakukan pada umur 39 HSS dengan, ditimbang dengan timbangan analitik.

e. Berat brangkasan kering (gram)

Dilakukan pada umur 39 HSS, dengan mengoven bibit pada suhu $80^{\circ} \mathrm{C}$ selama 48 jam.

f. Daya adaptasi lahan (\%)

Dilaksanakan pada umur 40 HSS selama 14 hari di lapang.

\section{Analisis Data}

Data dianalisis menggunakan Uji $\mathrm{F}$ 5\% dan 1\% (Anova), jika terdapat hasil yang signifikan maka dilanjutkan dengan uji BNT 5\%.

\section{HASIL DAN PEMBAHASAN}

Berdasarkan data pengamatan pada penelitian Analisis Aplikasi Media Tanam Terhadap Pertumbuhan Bibit Tembakau Bes-NO H382 Pada Sistem Pembibitan Semi Float Bed pada parameter tinggi bibit 
dan jumlah daun yang dilakukan 3 kali $(25$ HSS, 32 HSS, 39 HSS), diameter batang, berat basah bibit, berat kering bibit dilakukan pada pengamatan ke 3 (39 HSS). dan daya adaptasi lahan pada pengamatan ke 4 (14 HST), setelah dianalis diperoleh hasil yang disajikan pada Tabel 1 dibawah ini :

Tabel 1. Rangkuman Hasil Analisa Sidik Ragam Pengaruh Komposisi Media Terhadap Pertumbuhan Bibit Tembakau Besuki Na-Oogst varietas H 382 Semua Parameter Pengamatan

\begin{tabular}{llllcccccc}
\hline No & Parameter & \multicolumn{4}{c}{ F Hitung } & \multicolumn{3}{c}{ F Tabel } \\
\cline { 3 - 10 } & & 25 HSS & 32 HSS & 39 HSS & $\mathbf{5 \%}$ & $\mathbf{1 \%}$ \\
\hline 1 & Tinggi Bibit & 3,34 & $*$ & 2,28 & ns & 13,89 & $* *$ & 2,90 & 4,56 \\
2 & Jumlah Daun & 1,29 & ns & 1,67 & ns & 1,00 & Ns & 2,90 & 4,56 \\
3 & Diameter Batang & & & & & 6,60 & $* *$ & 2,90 & 4,56 \\
4 & Berat Brangkasan Basah & & & & & 20,72 & $* *$ & 2,90 & 4,56 \\
5 & Berat Brangkasan Kering & & & & & 4,79 & $* *$ & 2,90 & 4,56 \\
\hline
\end{tabular}

\begin{tabular}{|c|c|c|}
\hline terangan : & $\begin{array}{r}\mathrm{ns} \\
* \\
* *\end{array}$ & $\begin{array}{l}=\text { Non Signifikan } \\
=\text { Berbeda Nyata } \\
=\text { Berbeda Sangat Nyata } \\
\text { S }=\text { Hari Setelah Semai }\end{array}$ \\
\hline
\end{tabular}

Pada Tabel 1 terlihat bahwa parameter pengamatan tinggi bibit, diameter batang, berat brangkasan basah, berat brangkasan kering menunjukkan pengaruh berbeda sangat nyata, maka dari itu perlu dilakukan Uji BNT (Beda Nyata Terkecil) dengan taraf $5 \%$. Sedangkan pada parameter jumlah daun menunjukkan hasil berbeda tidak nyata (non signifikan).
Komponen
utama
dalam

berbudidaya adalah media tanam. Media tanam merupakan tempat berkembangnya akar dan hampir semua unsur hara yang dibutuhkan tanaman di serap melalui akar Media tanam yang digunakan harus sesuai dengan tanaman yang akan ditanam. Secara umum dalam menentukan media tanam yang tepat media tanam harus dapat menjaga kelembapan daerah sekitar akar, dapat menahan ketersediaan unsur hara, dan menyediakan cukup udara. Media tanam yang termasuk dalam kategori bahan organik umumnya berasal dari komponen organisme hidup, misalnya bagian dari tanaman seperti daun, batang, bunga, buah, atau kulit kayu. Beberapa jenis bahan organik yang dapat dijadikan sebagai media tanam diantaranya adalah arang, cacahan pakis, kompos, moss, cocopeat, humus dan pupuk kandang (Dalimoenthe, 2013).

Media tanam yang berbahan dasar organik biasanya mempunyai banyak keuntungan dalam beberapa aspek yaitu kualitasnya yang tidak bervariasi, bobot media lebih ringan, tidak mengandung inokulum penyakit, dan lebih bersih dibanding media tanam lainnya. Penggunan bahan organik sebagai media tanam didalam pembibitan jauh lebih unggul dibandingkan menggunakan bahan anorganik. Hal itu disebabkan karena media tanam yang berbahan organik mampu menyediakan unsur-unsur hara bagi tanaman. Selain hal tersebut, bahan organik pada dasarnya memiliki pori-pori makro dan mikro yang hampir seimbang sehingga sirkulasi udara yang dihasilkan cukup baik serta memiliki daya serap air yang tinggi (Dalimoenthe, 2013).

Sedangkan menurut Wira (2020) bahan-bahan untuk media tanam dapat dibuat dari bahan tunggal ataupun kombinasi dari beberapa bahan tertentu, 
asalkan bahan-bahan tersebut tetap berfungsi sebagai media tanam tumbuh yang baik. Sejalan dengan yang dikatakan Wiryanta (2007) bahwa media sphagnum moss ini sejenis lumut juga memenuhi kriteria media yang baik untuk pertumbuhan bibit yang optimal dengan melakukan kombinasi penambahan tanah humus maka dapat mengurangi asam-asam organik, yang dihasilkan selama proses dekomposisi yang bersifat racun bagi tanaman yang dapat menghambat pertumbuhan dan produktifitas tanaman. Menurut Gardner et al. (1991) faktorfaktor yang mempengaruhi pertumbuhan bukan hanya terletak pada media yang digunakan termasuk faktor eksternal (lingkungan) yang lain dan faktor internal (genetik).

\section{Tinggi Bibit}

Hasil analisa sidik ragam tinggi bibit tembakau pada Tabel 1 terlihat bahwa menunjukkan pengaruh yang berbeda nyata disetiap perlakuan. Pada pengamatan 32 HSS terlihat berbeda nyata, sedangkan pada pengamatan 25 HSS dan pengamatan 39 HSS dari hasil analisa terlihat berbeda sangat nyata maka dilakukan uji lanjut BNT 5\% yang di sajikan pada Tabel 2 :

Tabel 2. Hasil Uji Lanjut BNT $5 \%$ Terhadap Tinggi Bibit (cm) pada umur 39 HSS

\begin{tabular}{cccc}
\hline Perlakuan & Rerata & BNT 5\% & Notasi \\
\hline P0 & 4,06 & & $\mathrm{a}$ \\
P1 & 3,61 & & $\mathrm{ab}$ \\
P2 & 3,17 & 0,52 & $\mathrm{bc}$ \\
P3 & 3,10 & & $\mathrm{c}$ \\
P4 & 2,73 & $\mathrm{~cd}$ \\
P5 & 2,25 & $\mathrm{~d}$ \\
\hline
\end{tabular}

Keterangan : Angka-angka yang diikuti dengan huruf kecil yang sama menunjukkan berbeda tidak nyata (non signifikan) pada uji BNT taraf 5\%.

Berdasarkan uji lanjut BNT taraf 5\% pada Tabel 2 menunjukkan bahwa perlakuan P0, P3, P5 berbeda nyata dengan perlakuan lainnya. Pada perlakuan P0 dengan rerata $(4,06 \mathrm{~cm})$ menggunakan media $100 \%$ sphagnum moss menunjukkan berbeda tidak nyata dengan P1 yang memiliki rerata $(3,61)$.

Tinggi bibit pada P0 memiliki rerata yang lebih tinggi dari perlakuan lainnya dan P1 memiliki rerata yang berbeda tidak nyata dengan $\mathrm{P} 0$. Hal ini disebabkan oleh komposisi media sphagnum moss yang digunakan lebih banyak. Menurut Prameswari et al. (2014) bahwa sphagnum moss memiliki kandungan unsur $\mathrm{N} 0.86 \%, \mathrm{P} \quad 0.13 \%, \mathrm{~K}$ $0.80 \%, \mathrm{Ca} 0.30 \%, \mathrm{Mg} 0.26 \%$ dan Mn 0.17 $\%$, dimana tinggi bibit dipengaruhi oleh akar secara maksimal menyerap unsur hara yang tersedia dalam media, sehingga memacu pertumbuhan tanaman. Selain itu media sphagnum moss memiliki kadar lengas $35,42 \%$ yaitu kemampuannya dalam mengikat air sampai $80 \%$, mengandung nitrogen $2-3 \%$ dan sangat baik untuk perkembangan akar tanaman muda. Menurut Salisbury \& Ross (1995) mengatakan bahwa ketersediaan air yang memadai untuk memenuhi kebutuhan air bagi pertumbuhan tanaman sangat penting. Peranan air pada pembibitan semi float bed sebagai pelarut berbagai senyawa molekul organik (unsur hara) dari media keseluruh tanaman, untuk menjaga turgiditas sel diantaranya dalam pembesaran sel dan membukanya stomata, sebagai penyusun utama dari protoplasma. Apabila 
ketersediaan air pada media tanam kurang maka akan berakibat pada fotosintesis karena air sebagai bahan baku fotosintesis tidak optimal, proses transportasi unsur hara ke tanaman akan terhambat sehingga akan berdampak pada produksi bibit yang dihasilkan.

Pertumbuhan bibit tembakau memerlukan unsur hara makro yakni unsur Nitrogen yang berfungsi sebagai pembentuk klorofil yang berperan penting dalam proses fotosintesis, juga sebagai pembentuk protein, lemak dan berbagai persenyawaan organik lainnya (Millar \& Heazlewood, 2003). Pertumbuhan tinggi bibit merupakan bentuk cerminan akar secara maksimal menyerap unsur hara yang tersedia sehingga memacu pertumbuhan tanaman Media tanam merupakan tempat berkembangnya akar dan hampir semua unsur hara yang dibutuhkan tanaman di serap melalui akar. Hal ini sependapat dengan Sutedjo \& Kartasapoetra (2002) yang menyatakan bahwa pertumbuhan tinggi tanaman memerlukan unsur $\mathrm{N}$, $\mathrm{P}$ dan $\mathrm{K}$ untuk merangsang pertumbuhan batang, cabang dan daun dalam jumlah yang seimbang. Hal ini didapatkan dari media sphagnum moss yang memiliki kandungan hara tinggi, dengan dilakukannya pengeringan kolam 1 minggu sekali bertujuan merangsang akar bibit tumbuh dan diduga perakaran bibit tembakau sudah menembus pottray dan menyerap unsur hara dari media dan air yang akan di translokasikan ketanaman untuk pertumbuhan vegetatifnya.

\section{Jumlah Daun}

Jumlah daun merupakan salah satu parameter agronomi yang dapat digunakan untuk mengukur tingkat pertumbuhan tanaman. Berdasarkan hasil analisa sidik ragam jumlah daun bibit pada Tabel 1 menunjukkan pengaruh yang berbeda tidak nyata (non signifikan).
Berdasarkan hasil sidik ragam pada Tabel 1 dapat diketahui bahwa perlakuan media sphagnum moss dan top soil menunjukkan pengaruh berbeda tidak nyata pada seluruh perlakuan. Hal ini diduga karena pengaruh faktor internal (genetis) dan faktor penyinaran dan unsur hara yang terdapat pada media tanam belum diserap secara optimal oleh tanaman pada awal pertumbuhan. Hal ini sesuai dengan pernyataan Sutedjo (2010) yang menyatakan bahwa kemampuan tanaman menyerap unsur hara selama pertumbuhan dan perkembangan (terutama dalam hal pengambilan dan penyerapan) adalah tidak sama. Tanaman membutuhkan waktu dan jumlah unsur hara yang berbeda, selama pertumbuhan dan perkembanganya terhadap berbagai proses pertumbuhan intensitasnya berbeda-beda.

Daun merupakan organ tanaman yang berfungsi untuk menangkap cahaya matahari yang digunakan untuk fotosintesis, karena semakin banyak jumlah daun maka semakin banyak pula cahaya yang terserap oleh tanaman untuk proses fotosintesis yang berpengaruh terhadap pertumbuhan dan perkembangan tanaman (Gardner et al., 1991)

Jumlah daun dipengaruhi oleh unsur hara baik mikro maupun makro yang digunakan oleh tanaman untuk membentuk sel-sel baru. Pada dasarnya media yang baik untuk digunakan untuk menunjang pertumbuhan jumlah daun yang optimal yaitu media yang subur, dapat menyimpan air cukup baik, menyediakan cukup udara, dan memiliki ketersediaan unsur hara maka akan membantu bertambahnya jumlah daun pada tanaman (Sutedjo, 2010)

\section{Diameter Batang}

Hasil analisa sidik ragam diameter batang bibit tembakau pada Tabel 1, menunjukkan pengaruh yang berbeda sangat nyata. Hal ini selaras dengan pengertian pertumbuhan dan perkembangan, yaitu tanaman yang 
semakin tumbuh tinggi maka juga akan menambah ukuran tanaman (Sitompul \& Guritno, 1995), sehingga perlu dilakukan uji lajut menggunakan BNT 5\% yang di sajikan dalam Tabel 3 .

Tabel 3. Hasil Uji Lanjut BNT 5\% Parameter Diameter Batang (mm) pada umur 39 HSS

\begin{tabular}{cccc}
\hline Perlakuan & Rerata & BNT 5\% & Notasi \\
\hline P0 & 2,48 & & $\mathrm{a}$ \\
P1 & 2,54 & & $\mathrm{a}$ \\
P2 & 2,39 & 0,19 & $\mathrm{ab}$ \\
P3 & 2,29 & & $\mathrm{bc}$ \\
P4 & 2,21 & & $\mathrm{bc}$ \\
P5 & 2,13 & & $\mathrm{c}$ \\
\hline
\end{tabular}

Keterangan : Angka-angka yang diikuti dengan huruf kecil yang sama menunjukkan berbeda tidak nyata (non signifikan) pada uji BNT taraf $5 \%$.

Berdasarkan uji lanjut BNT taraf 5\% pada Tabel 3 menunjukkan bahwa perlakuan P0 (100\% sphagnum moss), P1 (90\% sphagnum moss : $10 \%$ top soil) dan P2 (80\% Sphagnum moss : 20\% top soil) menunjukkan hasil berbeda tidak nyata, dimana P1 memiliki rata-rata terbesar dari perlakuan lainnya. Hal ini diduga karena adanya tambahan media top soil menambah unsur hara yang mempengaruhi bertambahnya jaringan pembuluh sehingga menyebabkan bertambahnya diameter batang. Uminawar et al. (2013) menyatakan pertumbuhan diameter batang disebabkan oleh faktor genetik dari pertumbuhan bibit dan ketersediaan unsur hara dalam media. Pertambahan diameter batang diakibatkan oleh penambahan tebal batang. Bertambahnya tebal batang ini disebabkan karena semakin berkembang dan bertambahnya jaringan permbuluh yang ada pada tanaman. Aktivitas penambahan tebal batang adalah aktivitas menyertai pertambahan tinggi tanaman.

Media sphagnum moss dan tanah top soil yang mempunyai daya mengikat air dan mampu meningkatkan ketersediaan unsur hara, sehingga mampu meningkatkan pertumbuhan tanaman.
Penyerapan unsur hara $\mathrm{N}, \mathrm{P}$, pengairan dan temperatur merupakan proses penyerapan ion yang ditransportasi dari sel ke sel untuk proses metabolisme. Terbentuknya jaringan tanaman akibat pengaruh proses pembelahan sel yang saling terhubung antara sel-sel jaringan tanaman. Pada fase vegetatif, nitrogen yag diserap terlibat dalam senyawa pembentukan karbohidrat yang digunakan untuk pembentukan protoplasma pada titik tumbuh batang dan akar, sehingga organ jaringan tanaman akan mengalami penambahan ukuran yang berpengaruh terhadap pembentukan akar, batang dan daun (Wijaya, 2008).

\section{Berat Brangkasan Basah}

Hasil analisa sidik ragam berat brangkasan basah bibit tembakau pada Tabel 1 menunjukkan pengaruh yang berbeda nyata disetiap perlakuan. Karena $\mathrm{F}$ hitung lebih besar dari $\mathrm{F}$ tabel pada taraf $5 \%$, maka dilakukan uji lanjut menggunakan BNT taraf 5\%. Hasil uji BNT 5\% dapat dilihat pada Tabel 4. 
Tabel 4. Hasil Uji Lanjut BNT 5\% Parameter Berat Brangkasan Basah (gram) pada umur 39 HSS

\begin{tabular}{cccc}
\hline Perlakuan & Rerata & BNT 5\% & Notasi \\
\hline P0 & 1,84 & & $\mathrm{a}$ \\
P1 & 1,92 & 0,20 & $\mathrm{a}$ \\
P2 & 1,57 & & $\mathrm{~b}$ \\
P3 & 1,52 & $\mathrm{~b}$ \\
P4 & 1,38 & $\mathrm{~b}$ \\
P5 & 1,08 & $\mathrm{c}$ \\
\hline
\end{tabular}

Keterangan : Angka-angka yang diikuti dengan huruf kecil yang sama menunjukkan berbeda tidak nyata (non signifikan) pada uji BNT taraf 5\%

Tabel 4 menunjukkan bahwa P1 ( $90 \%$ sphagnum moss $+10 \%$ top soil) memiliki rerata tertinggi dari perlakuan lainnya, namun hasil uji lanjut menunjukkan berbeda tidak nyata dengan P0 (100\% spgahnum moss) dan berbeda nyata dengan perlakuan lainnya. Hal ini diduga karena P0 dan P1 tidak jauh berbeda dengan penambahan top soil yang mempunyai unsur hara $\mathrm{N} 0,081 \%$ dan bahan organik 1,191 \% dan kandungan media sphagnum moss itu sendiri sehingga mampu meningkatkan berat segar tajuk.

Berat segar tajuk merupakan berat tanaman setelah dipanen sebelum tanaman tersebut layu dan kehilangan air, selain itu berat segar tajuk merupakan total berat seluruh bagian tanaman yang menunjukkan hasil aktifitas metabolisme tanaman. Berat segar merupakan hasil pengukuran dari berat segar biomassa tanaman sebagai akumulasi bahan yang dihasilkan selama pertumbuhan tanaman (Buntoro et al., 2014)..

Unsur hara dan air yang diserap tanaman melalui akar akan mempengaruhi pertumbuhan tanaman. Akumulasi dari pertumbuhan tanaman akan mempengaruhi berat segar bibit tembakau, yang mana semakin baik pertumbuhan bibit tembakau maka semakin meningkat pula berat segar tanaman. Peningkatan berat segar tajuk dan berat segar total diduga karena unsur hara yang dibutuhkan oleh bibit dalam jumlah cukup sehingga mampu menunjang pertumbuhan tembakau. Peningkatan biomassa disebabkan tanaman menyerap air dan unsur hara dengan baik, sehingga memacu perkembangan organ-organ tanaman. Proses metabolisme termasuk aktifitas fotosintesis yang mengalami peningkatan sehingga mempengaruhi berat segar tajuk bibit tembakau. Peningkatan berat segar total dipengaruhi oleh penyerapan unsur hara yang dilakukan oleh akar dimana media sphagnum moss dapat mengikat air hingga $80 \%$ sehingga tanaman mengalami pertumbuhan akar yang optimal dan semakin luas menyerap unsur hara dan air dalam tanah. Hasil fotosintat digunakan tanaman untuk pertumbuhan dan perkembangan, sehingga berat segar tanaman akan mengalami peningkatan (Salisbury \& Ross, 1995)

\section{Berat Brangkasan Kering}

Pengamatan berat brangkasan kering dilakukan di akhir pengamatan pada umur $39 \mathrm{HSS}$, dimana seluruh parameter pengamatan sudah dilakukan. Pengamatan ini dengan menimbang berat brangkasan bibit yang sudah di keringkan dengan oven dengan suhu $80^{\circ} \mathrm{C}$ selama $2 \times 24$ jam. untuk mengetahui laju pertumbuhan dengan membandingkan berat basah dan berat kering brangkasan. Berdasarkan Tabel 1 menunjukkan berbeda sangat nyata pada parameter berat brangkasan kering, maka dilakukan uji lanjut BNT 5\% yang dapat dilihat pada Tabel 5 
Tabel 5. Hasil Uji Lanjut BNT 5\% Parameter Berat Brangkasan Kering (gram) pada umur 39 HSS

\begin{tabular}{cccc}
\hline Perlakuan & Rerata & BNT 5\% & Notasi \\
\hline P0 & 0,15 & & ab \\
P1 & 0,17 & 0,03 & $\mathrm{a}$ \\
P2 & 0,13 & & $\mathrm{bc}$ \\
P3 & 0,13 & $\mathrm{bc}$ \\
P4 & 0,12 & $\mathrm{bc}$ \\
P5 & 0,10 & $\mathrm{c}$ \\
\hline
\end{tabular}

Keterangan : Angka-angka yang diikuti dengan huruf kecil yang sama menunjukkan berbeda tidak nyata (non signifikan) pada uji BNT taraf 5\%.

Berdasarkan uji lanjut BNT 5\% menunjukkan hasil bahwa P1, P0 dan P5 berbeda nyata dengan P2, P3, P4. Pada pengamatan berat brangkasan kering $\mathrm{P} 1$ memiliki rerata tertinggi $(0,17$ gram $)$ dari perlakuan lainnya. Pengukuran berat brangkasan kering bibit bertujuan untuk mengetahui rendemen dan kecepatan laju pertumbuhan dimana unsur hara yang diserap oleh tanaman dengan membandingkan berat brangkasan basah dan berat brangkasan kering.

Dwijoseputro (1978) mengatakan bahwa berat total kering tanaman merupakan hasil keseimbangan antara pengambilan karbondioksida dan pengeluaran oksigen secara nyata ditunjukan pada berat basah tanaman, begitu pula dengan laju fotosintesis yang berpengaruh terhadap berat kering tanaman dikarenakan semakin tingginya laju fotosintesis maka akan meningkatkan berat brangkasan kering bibit.

Hasil analisa uji lanjut BNT 5\% menunjukkan bahwa rerata berat brangkasan kering tertinggi dicapai oleh perlakuan media P1 (90\% sphagnum moss dan $10 \%$ top soil). Hal ini diduga karena kandungan unsur hara nitrogen pada sphagnum moss dan tanah top soil lebih besar dibandingkan dengan perlakuan yang lainnya. Unsur nitrogen berperan penting dalam pembentukan hijau daun yang berguna sekali dalam proses fotosintesis. Fotosintesis menghasilkan karbohidrat dalam tanaman. Ketersediaan nitrogen berpengaruh terhadap berat brangkasan kering yang merupakan hasil dari penimbunan bahan kering.. Oleh karena itu tanaman yang pertumbuhan daunnya baik akan mempunyai laju fotosintesis yang tinggi sehingga mampu menghasilkan bahan kering yang tinggi pula.

Pengamatan daya adaptasi lapang dilakukan pada umur 14 HST. Pengamatan ini di tujukan untuk mengetahui daya adaptasi bibit ke media yang baru (lapang). Hasil pengamatan dapat dilihat pada Tabel 6.

Tabel 6. Hasil Parameter Daya Adaptasi Lapang (\%) pada umur 14 HST

\begin{tabular}{cccc}
\hline \multirow{2}{*}{ Perlakuan } & Tanaman & Tanaman Hidup & \multicolumn{2}{c}{ Persentase } \\
\cline { 4 - 4 } & Ditanam & Jumlah Tanaman Hidup & Jumlah Tanaman Ditanam \\
P0 & 4 & 4 & $100 \%$ \\
P1 & 4 & 4 & $100 \%$ \\
P2 & 4 & 3 & $75 \%$ \\
P3 & 4 & 4 & $100 \%$ \\
P4 & 4 & 4 & $100 \%$ \\
P5 & 4 & 4 & $100 \%$ \\
\hline
\end{tabular}


Berdasarkan hasil Tabel 6, Parameter Daya Adaptasi Lapang dengan jumlah 4 ulangan dari 6 perlakuan, menunjukkan tanaman hidup sehat dan memiliki daya adaptasi yang baik semua kecuali P2. Dimana didapatkan seluruh perlakuan menunjukkan presentase daya adaptasi lapang $100 \%$, kecuali P2 sebesar $75 \%$.

Semua perlakuan memiliki presentase hidup 100\% kecuali perlakuan P2, karena ada satu tanaman mati. Adapun faktor yang di duga mempengaruhi pada angka presentase hidup adalah, ketersediaan unsur hara yang cukup dan kondisi lingkungan yang optimum sehingga bibit mampu tumbuh dengan optimum. Menurut (Sholeh, 2006) kriteria bibit yang baik yaitu memiliki tinggi bibit 10-15 cm, jumlah daun 5-6 helai, diameter $0,6 \mathrm{~cm}$, sehat, tidak terlalu subur (sukulen) dan tidak terlalu kurus, perakaran baik, bebas dari hama dan penyakit Bibit yang siap tanam dapat beradaptasi di lapang dengan baik karena bibit sudah tumbuh dengan optimal di pembibitan sehingga siap saat dipindah ke media di lapang.

Pada perlakuan P1 dan P0 berbeda tidak nyata pada seluruh parameter dimana komposisi media sphagnum moss dan top soil ini memiliki cukup unsur hara untuk mendukung pertumbuhan bibit supaya bibit beradaptasi dengan baik. Selain itu juga dipengaruhi oleh sisten pembibitan menggunakan potray sehingga akar dan media tanam pada bibit terjaga di dalam potray sehingga pada saat penanaman dilapang tidak terjadi putusnya akar, sehingga pertumbuhan baik.

Menurut penelitian Syafrudddin et al. (2018) menyatakan adaptasi tanaman dilapang merupakan salah satu upaya untuk mengetahui kesesuaian terhadap lahan untuk memperoleh hasil maksimal dan efisiensi usaha tani. Adaptasi lapang ini digunakan untuk melihat kualitas bibit yang dapat tumbuh dengan optimum, sedang bibit yang tidak berkualitas maka tidak dapat beradaptasi dengan baik sehingga menyebabkan kerugian saat penyulaman, selain itu bibit yang memiliki kualitas baik mempengaruhi produksi dan pendapatan petani.

\section{KESIMPULAN}

Berdasarkan hasil dan pembahasan dalam penelitian ini dapat disimpulkan bahwa pertumbuhan bibit tembakau BesNO H 382 pada sistem semi float bed dipengaruhi oleh aplikasi komposisi media tanam dengan hasil pertumbuhan bibit terbaik pada perlakuan komposisi sphagnum moss:top soil $90 \%: 10 \%$ dan 100\% : $0 \%$ dengan rerata tinggi bibit 3,61$4,06 \mathrm{~cm}$, diameter batang 2,48-2,54 $\mathrm{mm}$, berat brangkasan basah 1,84-1,92 gram dan berat brangkasan kering 0,15-0,17 gram pada umur bibit 39 HSS. Selain itu, jumlah daun tidak dipengaruhi oleh aplikasi media tanam tetapi daya adaptasi bibit sangat baik di lahan karena prosentase hidup bibit mencapai $75-100 \%$ pada semua perlakuan.

\section{DAFTAR PUSTAKA}

Buntoro, B. H., Rogomulyo, R., \& Trisnowati, S. (2014). Pengaruh Takaran Pupuk Kandang dan Intensitas Cahaya Terhadap Pertumbuhan dan Hasil Temu Putih (Curcuma zedoaria L.). Vegetalika, 3(4), 29-39.

Dalimoenthe, S. L. (2013). Pengaruh media tanam organik terhadap pertumbuhan dan perakaran pada fase awal benih teh di pembibitan. Jurnal Penelitian Teh Dan Kina, 16(1), 111.

Dwijoseputro, D. (1978). Pengantar Fisiologi Tumbuhan, Jakarta: PT. Gramedia. Jakarta.

Gardner, F. P., Pearce, R. B., \& Mitchell, R. L. (1991). Fisiologi tanaman budidaya.

Hardjowigeno, S. (2007). Evaluasi Kesesuaian Lahan dan Perancangan Tataguna Lahan. Gadjah Mada University Press. 
Humaida, S., \& Erawati, D. N. (2020). Pasca Panen Tembakau. Polije Press.

Islami, T., \& Utomo, W. . (1995). Hubungan Tanah, Air dan Udara. IKIP Semarang Press.

Millar, A. H., \& Heazlewood, J. L. (2003). Genomic and proteomic analysis of mitochondrial carrier proteins in Arabidopsis. Plant Physiology, 131(2), 443-453.

Prameswari, Z. K., Trisnowati, S., \& Waluyo, S. (2014). Pengaruh macam media dan zat pengatur tumbuh terhadap keberhasilan cangkok sawo (Manilkara zapota (L.) van Royen) pada musim penghujan. Vegetalika, 3(4), 107-118.

Salisbury, F. B., \& Ross, C. W. (1995). Fisiologi tumbuhan. (D. R. Lukman \& Sumaryono, Eds.) (Terjemahan). Bandung: Institut Teknologi Bandung.

Saputro, D. . (2019). Pengaruh Macam Media Tanam Terhadap Pertumbuhan Bibit Tembakau White Burley (Nicotiana tabacum L.) pada Pembibitan Semi Float Bed. Politeknik Negeri Jember.

Sholeh, M. (2006). Paket Teknologi Budidaya Tembakau Cerutu Besuki di Jember Selatan (Vol. 1). Malang: Balai Penelitian Tanaman Tembakau dan Serat.

Siregar, R. P., Ginting, J., \& Meiriani, M. (2018). Pertumbuhan dan Produksi Tembakau Deli (Nicotiana tabacum L.) pada Pemberian Pupuk KNO3 dan Pupuk Organik Cair Urin Kelinci. AGROEKOTEKNOLOGI, 6(2, April).

Sitompul, S. M., \& Guritno, B. (1995). Analisis pertumbuhan tanaman.

Sutedjo, M M. (2010). Pupuk dan Cara Pemupukan. PT. Rineka Cipta. Jakarta.

Sutedjo, Mul Mulyani, \& Kartasapoetra, A. G. (2002). Pengantar ilmu tanah.

Syafrudddin, Irmawadayanti, A., \& Saidah. (2018). Adaptasi Bawang
Merah dan Kacang Tanah Pada Lahan Kering di Parigi Moutong Sulawesi Tengah. Jurnal Pengkajian Dan Pengembangan Teknologi Pertanian, 21(1).

Uminawar, U., Umar, H., \& Rahmawati, R. (2013). Pertumbuhan Semai Nyatoh (Palaquium sp.) pada Berbagai Perbandingan Media dan Konsentrasi Pupuk Organik Cair di Persemaian. Jurnal Warta Rimba, 1(1).

Wijaya, K. A. (2008). Nutrisi tanaman: sebagai penentu kualitas hasil dan resistensi alami tanaman.

Wira, N. . (2020). Pengaruh Campuran Bahan Organik terhadap Pertumbuhan dan Hasil Tanaman Seledri. Universitas Mataram.

Wiryanta, B. T. W. (2007). Media tanam untuk tanaman hias. AgroMedia. 